\title{
Longitudinal retrospective study on the effect of season on milk production and composition in Rio Grande do Sul, Brazil
}

\section{Estudo retrospectivo longitudinal sobre o efeito da estação na produção e composição do leite no Rio Grande do Sul, Brasil}

\author{
Sirineu José Sicheski ${ }^{1}$; Ione Maria Pereira Haygert-Velho ${ }^{2}$; Marcos André Piuco ${ }^{3}$; \\ Marcos Busanello ; Júlia Laize Bandeira Calgaro ${ }^{5}$; Paulo Sérgio Gois Almeida ${ }^{2}$; \\ Jardel Menegazzi da Conceição ${ }^{6}$; João Pedro Velho ${ }^{2 *}$
}

\begin{abstract}
Highlights:
Variation in milk composition can be reduced by effective planning and training. Integrative approaches can maintain milk quality and generate extra revenue. Seasons affect milk production but supplemental feeding can minimize this effect. A systemic and integrated approach can increase efficiency of milk production.
\end{abstract}

\begin{abstract}
This longitudinal retrospective study evaluated production and composition of milk from dairy cows according to season on a rural property in Palmeira das Missões, Rio Grande do Sul, Brazil, between January 2009 and December 2016. Milk yield per hectare per month was the primary variable measured, along with chemical composition (total dry extract, defatted dry extract, fat, protein, and lactose), somatic cell count, and total bacterial count of milk. Production in summer $(513.53 \mathrm{~kg} / \mathrm{ha} / \mathrm{month})$ did not differ $(p>0.05)$ from that in fall $(504.69 \mathrm{~kg} / \mathrm{ha} / \mathrm{month})$ or spring $(564.63 \mathrm{~kg} / \mathrm{ha} / \mathrm{month})$, but production in winter $(639.20 \mathrm{~kg} / \mathrm{ha} /$ month $)$ was significantly higher than in summer $(p<0.0057)$. The real price of milk did not differ $(p>0.05)$ among seasons. The total dry extract content differed $(p<$ 0.0059 ) between seasons. However, the cooler fall and winter seasons favored the production of total solids. The defatted dry extract content was higher $(p<0.0001)$ in winter $(8.65 \%)$, compared to the other seasons of the year. Fat content did not differ $(p>0.05)$ among seasons. Protein content differed $(p<0.0200)$ between summer $(3.01 \%)$ and winter $(3.16 \%)$, but both seasons did not differ $(p>0.05)$ from fall $(3.13 \%)$ or spring $(3.05 \%)$. Winter lactose levels $(4.52 \%)$ were higher $(p<0.0011)$ than during other seasons. The somatic cell count did not differ $(p>0.05)$ among seasons, demonstrating that the evaluated herd possesses standard mammary gland health. The total bacterial count did not differ $(p>$ 0.05 ) among the seasons, demonstrating that the hygiene of the facilities remains constant. As expected, the temperature and humidity index varied $(p<0.0001)$ with the seasons, and the deleterious effects
\end{abstract}

\footnotetext{
${ }^{1}$ Discente do Curso de Doutorado, Programa de Pós-Graduação em Agronegócios, Universidade Federal do Rio Grande do Sul, UFRGS, Porto Alegre, RS, Brasil. E-mail: sirineu.sicheski@iffarroupilha.edu.br

2 Profs., Departamento de Zootecnia e Ciências Biológicas, Universidade Federal de Santa Maria, UFSM, Campus de Palmeira das Missões, Palmeira das Missões, RS, Brasil. E-mail: ione.h.velho@ufsm.br; paulo.almeida@ufsm.br; velhojp@ufsm.br

3 Prof., Escola Estadual Técnica Celeste Gobbato, EETCG, Palmeira das Missões, RS, Brasil. E-mail: piucozoot@gmail.com

4 Discente do Curso de Doutorado, Programa de Pós-Graduação em Ciência Animal e Pastagens, Universidade de São Paulo, USP, Escola Superior de Agricultura Luiz de Queiroz, ESALQ, Piracicaba, SP, Brasil. E-mail: marcosbusanello@usp.br

5 Discente do Curso de Mestrado, Programa de Pós-Graduação em Agronegócios, UFSM, Campus de Palmeira das Missões, Palmeira das Missões, RS, Brasil. E-mail: julia calgaro@hotmail.com

6 Discente do Curso de Graduação em Zootecnia, UFSM, Campus de Palmeira das Missões, Palmeira das Missões, RS, Brasil. E-mail: j.menegazzi@hotmail.com

* Author for correspondence
} 
were more pronounced in summer and spring, as they are the hottest seasons in humid subtropical environments. The results emphasize that the organized management of milk production reduces the variation in milk composition, making it easier to maintain a consistent high milk quality and also generating extra revenue.

Key words: Dairy farms. Lactose. Milk prices. Production system. Temperature-humidity index.

\section{Resumo}

Este estudo retrospectivo longitudinal avaliou a produção e a composição do leite de vacas leiteiras de acordo com a estação em uma propriedade rural em Palmeira das Missões, Rio Grande do Sul, Brasil, entre janeiro de 2009 e dezembro de 2016. A produção de leite por hectare por mês foi a principal variável mensurada, juntamente com a composição química (extrato seco total, extrato seco desengordurado, gordura, proteína e lactose), contagem de células somáticas e contagem bacteriana total de leite. A produção no verão $(513,53 \mathrm{~kg} / \mathrm{ha} /$ mês $)$ não diferiu $(p>0,05)$ daquela no outono $(504,69 \mathrm{~kg} / \mathrm{ha} / \mathrm{mês})$ ou primavera $(564,63 \mathrm{~kg} / \mathrm{ha} / \mathrm{mês})$, mas a produção no inverno $(639,20 \mathrm{~kg} / \mathrm{ha} / \mathrm{mês})$ foi significativamente maior que no verão $(p<0,0057)$. O preço real do leite não diferiu $(p>0,05)$ entre as estações. $\mathrm{O}$ teor total de extrato seco diferiu $(p<0,0059)$ entre as estações. No entanto, as estações mais frias do outono e inverno favoreceram a produção de sólidos totais. $\mathrm{O}$ teor de extrato seco desengordurado foi maior $(p<0,0001)$ no inverno $(8,65 \%)$, em relação as demais estações do ano. O conteúdo de gordura não diferiu $(p>0,05)$ entre as estações. O conteúdo de proteína diferiu $(p<0,0200)$ entre o verão $(3,01 \%)$ e o inverno $(3,16 \%)$, mas as duas estações não diferiram $(p>0,05)$ do outono $(3,13 \%)$ ou da primavera $(3,05 \%)$. Os níveis de lactose no inverno $(4,52 \%)$ foram maiores $(p<0,0011)$ do que nas demais estações do ano. A contagem de células somáticas não diferiu $(p>0,05)$ entre as estações, demonstrando que o rebanho avaliado possui saúde padrão das glândulas mamárias. A contagem bacteriana total não diferiu $(p>0,05)$ entre as estações, demonstrando que a higiene das instalações permanece constante. Como esperado, o índice de temperatura e umidade variou $(p<0,0001)$ com as estações do ano e os efeitos deletérios foram mais pronunciados no verão e na primavera, por serem as estações mais quentes em ambientes subtropicais úmidos. Os resultados enfatizam que o manejo organizado da produção de leite reduz a variação na composição do leite, facilitando a manutenção de uma alta qualidade consistente do leite e também gerando receita extra.

Palavras-chave: Produtores de leite. Lactose. Preço do leite. Sistema de produção. Índice de temperatura e umidade.

\section{Introduction}

The production of animal products, such as meat, milk, and their derivatives, is intensifying globally to meet increasing market demand. However, this growing demand must be met in a sustainable manner (i.e., following the three pillars of sustainability: economically viable, environmentally correct, and socially just) (Tedeschi, Muir, Riley, \& Fox, 2015). Sustainability is especially important because the global population is expected to exceed eight billion people in 2030 (Samir \& Lutz, 2017) and nine billion people in 2050 (Alexandratos \& Bruinsma, 2012). At the same time, life expectancy is increasing due to social changes related to culture and health care (Salomon et al., 2012), increased income (Valin et al., 2014), and increased urbanization (Smith, 2017) all necessitating improved food security (Seto \& Ramankutty, 2016). It is thus crucial to understand the impacts of food production on human health (Patz, Campbell-Lendrum, Holloway, \& Foley, 2005; Liu et al., 2015; Tedeschi et al., 2017). For example, by naturally altering the fatty acid profile of milk and its derivatives, it is possible to create healthier foods that have improved nutraceutical characteristics (D. C. Silva et al., 2007; Ferlay, Doreau, Martin, \& Chilliard, 2013; Oeffner et al., 2013; Puppel, Kuczyńska, Nałęcz-Tarwacka, \& Grodzki, 2013).

Owing to the socioeconomic and nutritional importance of the Productive Milk Chain, the 
Ministério da Agricultura, Pecuária e Abastecimento of Brazil has issued normative instruction Nos. 76, 77, and 78 (Instrução Normativa $\mathrm{n}^{\mathrm{o}}$ 76, 77, 78, 2018a,b,c), which aim to improve the composition and quality of the milk produced in Brazil. However, milk production is the result of interactions between multiple factors, such as soil availability and soil fertility (Mueller, Baan, \& Koellner, 2014; Gerssen-Gondelach et al., 2017); waste management, nutrients, and the mitigation of greenhouse gases (Asselin-Balençon et al., 2013; Holly, Larsona, Powell, Ruark \& Aguirre-Villegas, 2017; Veltman et al., 2017); the availability, quality, and use of water (Coimbra, Machado, \& Hötzel, 2012; Willers, Ferraz, Carvalho, \& Rodrigues, 2014; Kraub, Kraatz, Drastig, \& Prochnow, 2015; Palhares \& Pezzopane, 2015); pasture production (Henz et al., 2016; Roche et al., 2017; Tambara et al., 2017); silage production (Hentz et al., 2017; N. C. Silva et al., 2018; Velho et al., 2020); cow genetics (R. P. A. Silva et al., 2015; Hardie et al., 2017; Rangel et al., 2018); feeding systems (Larsen et al., 2010; Fajardo et al., 2015; Virbat et al., 2017); and mammary health (Busanello, Rossi, Cassoli, Pantoja, \& Machado, 2017; Gonçalves et al., 2018), among several other parameters.

Thus, milk production is truly dynamic in nature, and a systematic and integrated approach to the industry that manages these factors could increase production efficiency. However, implementing this holistic and integrated approach is challenging because of the many interactive factors involved. Therefore, rural dairy producers in developing countries require technical assistance in the short, medium, and long term to streamline a dynamic approach to milk production that will increase profitability.

Stürmer, Busanello, Velho, Heck and HaygertVelho (2018) revealed that milk production, milk pricing, and composition in the municipality of Chapada in the northwest region of Rio Grande do Sul are closely associated with climatic variables. Specifically, $\sim 10.2 \%$ of the variation in milk composition, monthly production, and pricing was explained by a set of climatic variables, such as temperature, solar radiation, rainfall, and the temperature-humidity index (THI). However, climatic variables have an indirect influence on milk composition and quality, primarily as a result of the effect of heat stress on cows (Gantner et al., 2017), which causes substantial metabolic changes (e.g., reduction in lipolysis, increased glycolysis, increased catabolism of amino acids). Longterm heat stress also interferes with immune and inflammatory functions (Min et al., 2017).

The objective of the present study was to evaluate the milk production and chemical composition, somatic cell count (SCC), and total bacterial count (TBC) of milk in relation to season on a rural property in Palmeira das Missões, Rio Grande do Sul, Brazil, between January 2009 and December 2016. The study was delineated as a longitudinal retrospective according to the recommendations of Sargeant and O'Connor (2014).

\section{Material and Methods}

The data used in the present study (January 2009 to December 2016) originated from the Escola Estadual Técnica Celeste Gobbato (EETCG), Palmeira das Missões, Rio Grande do Sul, Brazil, which performs secondary vocational training of Técnicos em Agropecuária. The results were generated in the Unidade Educativa Bovinocultura de Leite (UEBL). Management of the Holstein herd and production conditions between January 2009 and December 2012 were described by HaygertVelho et al. (2018). The production system between January 2013 and December 2016 was the same.

For milk analysis, two to four samples from the cooling tank were collected monthly by the company that buys the milk from the EETCG. The samples were analyzed by the Serviço de Análise de Rebanhos Leiteiros of the Universidade de Passo Fundo, which is certified by the Ministerio da Agricultura, Pecuária e Abastecimento of Brazil. To determine the amounts of total dry extract (TDE), defatted dry extract (DDE), lactose, fat, and 
protein, the samples were analyzed by near-infrared spectroscopy. The SCC and TBC were determined using flow cytometry.

The THI was calculated according to official data from the meteorological database of the Instituto Nacional de Meteorologia for the Estação Meteorológica Automática de Palmeira das Missões (longitude: O 53 19 4.976; latitude: S 2755 13.364; altitude: $614 \mathrm{~m}$ ), which is nearly $2 \mathrm{~km}$ from the UEBL-EETCG management center. The climate of the region is characterized as $\mathrm{Cfa}$ (subtropical humid with hot summers and without a defined dry season), according to the Köppen classification system, with an average annual rainfall of 1,029 mm (Alvares, Stape, Sentelhas, Gonçalves, \& Sparovek, 2013). The formula used to determine the THI, according to Kibler (1964), is

$$
\mathrm{THI}=1.8 \times \mathrm{Ta}-(1-\mathrm{RH}) \times(\mathrm{Ta}-14.3)+32
$$

where $\mathrm{Ta}=$ mean daily temperature $\left({ }^{\circ} \mathrm{C}\right)$ and $\mathrm{RH}=$ mean daily relative air humidity as a fraction of the unit (MeanRH/100).

Oliveira, Moura, Neiva and Guilhermino (2001) established three categories of heat stress due to THI: THI posing mild stress $=72-79$, THI posing moderate stress $=80-89$, and THI posing severe stress $=90-98$. However, we used only two THI classes: smaller than $72(\mathrm{THI}<72)$ and greater than 72 (THI > 72).

The Índice Geral de Preços-Disponibilidade Interna, published by the Instituto Brasileiro de Economia [IBRE] in association with the Fundação Getúlio Vargas [FGV] (2016), was used to calculate the milk values, according to changing prices in the Brazilian economy. The IGP-DI is a weighted arithmetic average between the Índice de Preços no Atacado, which measures the variation in the wholesale prices; and the Índice de Preços ao Consumidor, which measures the price oscillation by the retail sector and consumer services (IBREFGV, 2016). The Real Price of Milk (RPM) was determined as follows:

$$
\mathrm{RPM}=\frac{\mathrm{NPM}}{\mathrm{IGP}-\mathrm{DI}} * 100
$$

where NPM $=$ Nominal Price of Milk. The base date used was 12/2016. Figure 1 shows the nominal and real prices of milk, considering the evaluation period of the EETCG herd (January 2009 to December 2016).

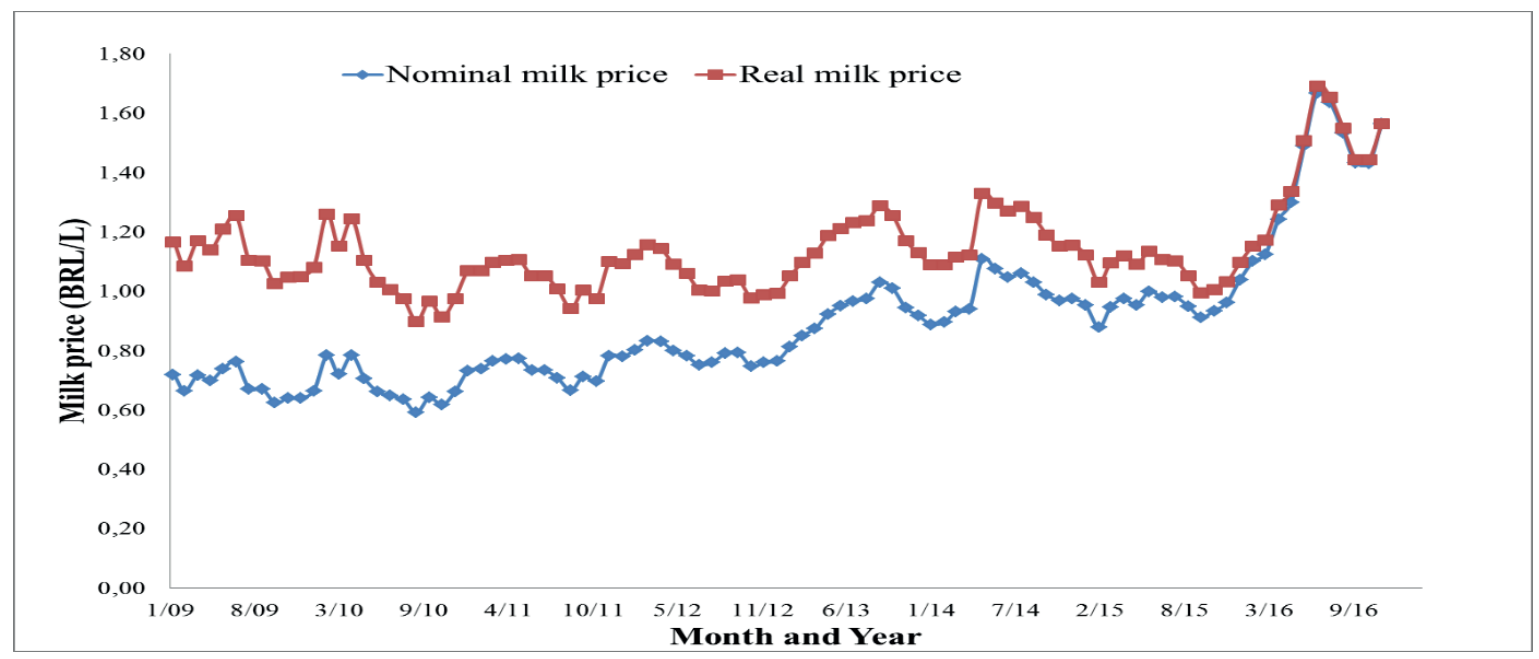

Figure 1. Nominal and real prices of milk (BRL/L), between January 2009 and December 2016, in Palmeira das Missões, Rio Grande do Sul, Brazil.

The exchange rate is a relation between the of one of them in relation to the other. This variable currencies of two countries that measures the price has great importance in an open economy and exerts 
a strong influence on other macroeconomic variables (Grijó, 2005). According to Bresser-Pereira (2012), a competitive exchange rate stimulates export-oriented investments and correspondingly increases domestic savings. Almeida and Bacha (1999) distinguished the real exchange rate from the effective exchange rate; the former refers to the deflated value of the price in the national currency of a unit of foreign currency taken as a reference. The real effective exchange rate is the deflated value of the domestic currency price of a weighted average of foreign currencies (Figure 2). Figure 3 shows the real price of milk (USD/L) received by the EETCG during the longitudinal retrospective study period.

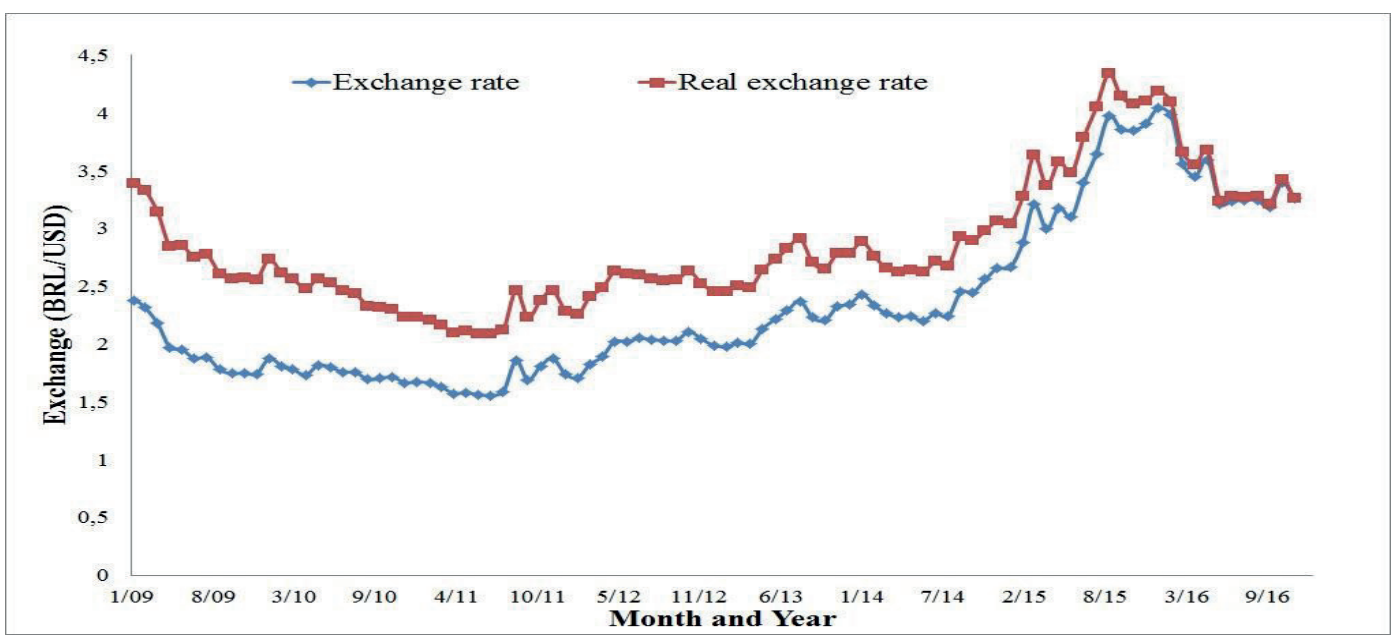

Figure 2. Exchange rate and real exchange rate (BRL/USD) between January 2009 and December 2016.

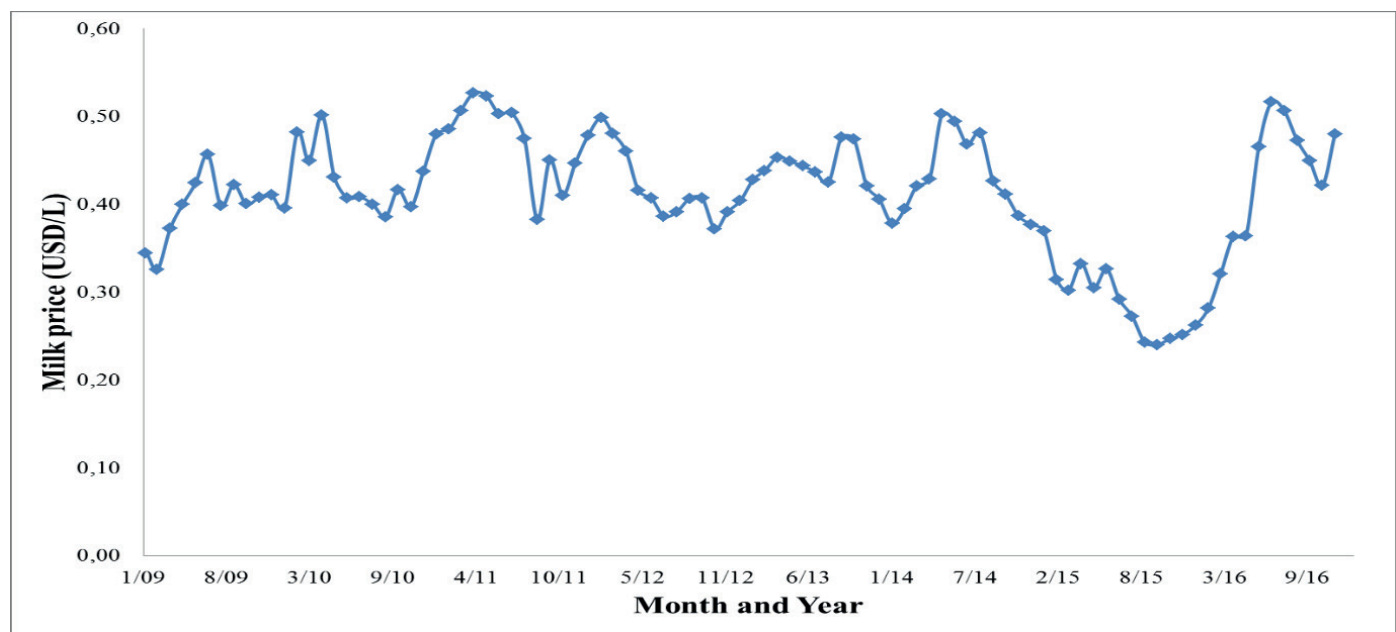

Figure 3. Real price of milk (USD/L) between January 2009 and December 2016, in Palmeira das Missões, Rio Grande do Sul, Brazil.

The statistical analyses (Table 1) and the nonparametric Kendall (Table 2) method PROC CORR SAS Institute, (2012) were used to assess the following variables in the database: milk production per hectare per month, milk price in USD, TDE,
DDE, fat, protein, lactose, SCC, TBC, and hours each month during which THI was below and above 72 . These methods were used to reveal trends in the data because variables such as SCC and TBC presented extreme values and were not normally distributed. 


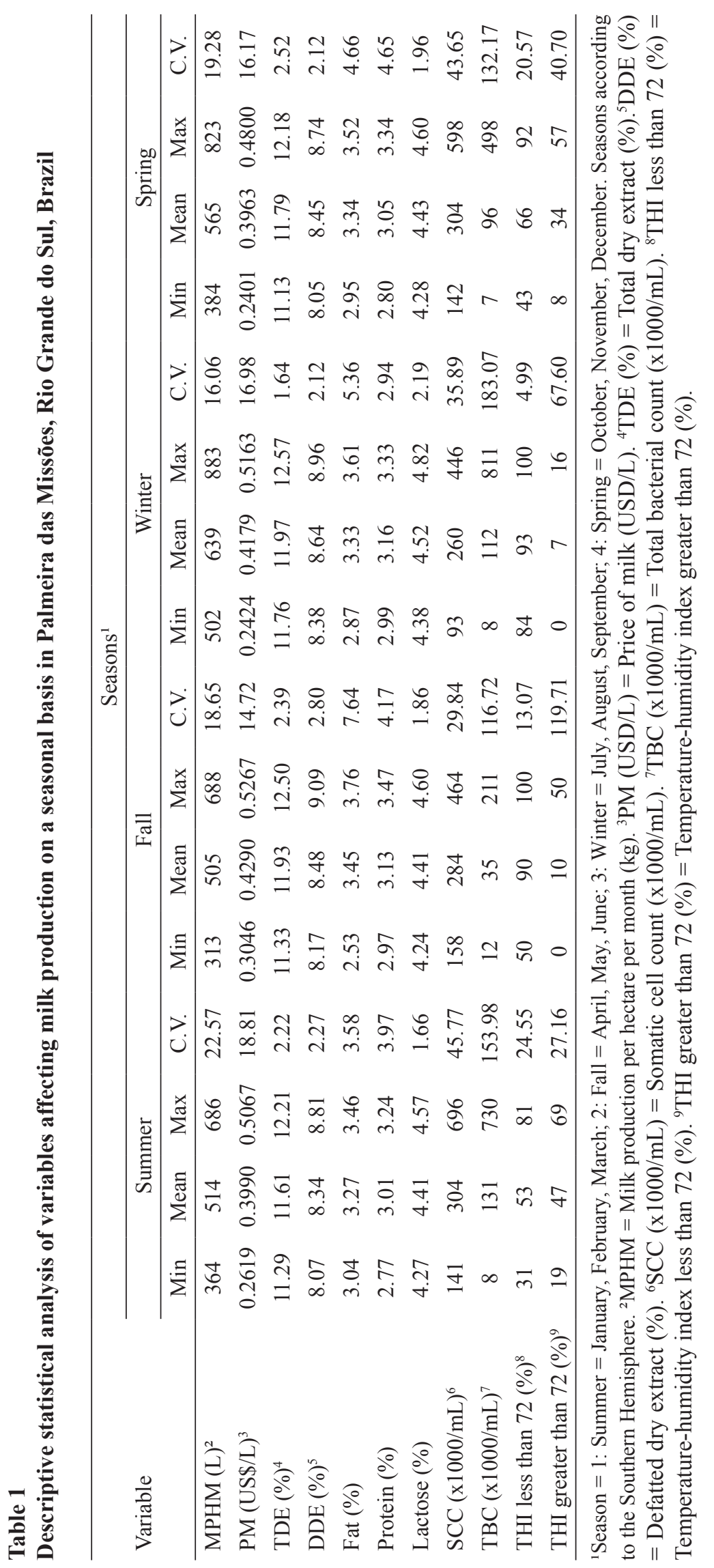




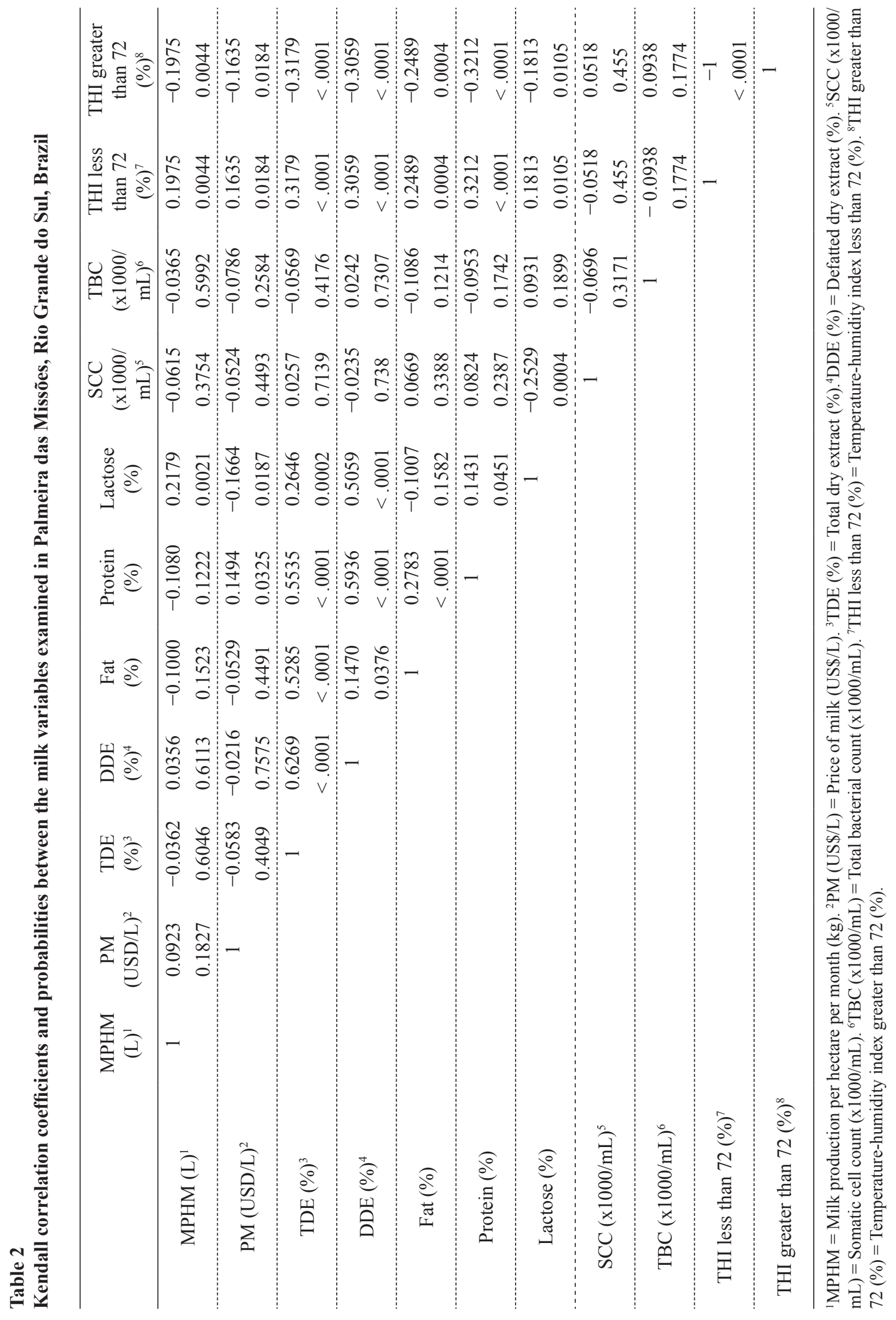

Semina: Ciências Agrárias, Londrina, v. 41, n. 4, p. 1355-1372, jul./ago. 2020 
The variables were also compared among seasons and years. To verify the influence of climatic southern-hemisphere seasons on the results, years were segmented into seasons as follows: summer (January, February, and March), fall (April, May, and June), winter (July, August, and September), and spring (October, November, and December). First, the distribution of data was determined for all the variables by means of histograms (SAS PROC UNIVARIATE). Subsequently, a generalized linear mixed model (PROC GLIMMIX in SAS) was applied to the variables that presented a normal distribution: milk yield per hectare, milk price in USD, TDE, DDE, fat, protein, and lactose, using month as a random effect and a variance-covariance matrix of the unstructured type to model the repeated measurements. This matrix resulted in the best fit of the model. A normal distribution was used to model these variables as follows:

$$
Y_{i j k}=\alpha+\beta_{i}+\gamma_{j}+\delta_{k}+\varepsilon_{i j k}
$$

where

$Y_{i j k}=$ value of the response variable within the $i^{\text {th }}$ season, $j^{\text {th }}$ year, and $k^{\text {th }}$ month;

$\alpha=$ value of intercept, common to all observations;

$\beta_{i}=$ fixed effect of the $i^{\text {th }}$ season of the year with $i$ $=4$;

$\gamma_{j}=$ fixed effect of the $j^{\text {th }}$ year with $j=8$;

$\delta_{k}=$ random effect of the $k^{\text {th }}$ month with $k=12$;

$\varepsilon_{i j k}=$ random error associated with observation.

For the other variables that did not present a normal distribution (SCC, TBC, hours each month during which THI was below and above 72), a model similar to the previous one was used with the same variance-covariance structure and the same fixed and random effects. However, a log-normal distribution was used, which allowed the best adjustment of the data. The model used was

$$
\log \left(Y_{i j k}\right)=\alpha+\beta_{i}+\gamma_{j}+\delta_{k}+\varepsilon_{i j k}
$$

where $\log \left(Y_{i j k}\right)=$ value of the response variable transformed into a natural logarithm within the $i^{\text {th }}$ season, $j^{\text {th }}$ year, and $k^{\text {th }}$ month;

$\alpha=$ intercept value, common to all observations;

$\beta_{i}=$ fixed effect of the $i^{\text {th }}$ season of the year with $i$ $=4$;

$\gamma_{j}=$ fixed effect of $j^{\text {th }}$ year with $j=8$;

$\delta_{k}=$ random effect of the $k^{\text {th }}$ month with $k=12$;

$\varepsilon_{i j k}=$ random error associated with observation.

The averages obtained as a result of this second modeling were retransformed and presented in the original scale of each variable. In addition, the residuals for both models were checked for normality by means of histograms (PROC UNIVARIATE of SAS), and when the $p$-value was significant, the Tukey-Kramer comparison test was used to differentiate among the seasons and years. Statistical differences were considered significant at the $0.05(5 \%)$ level of probability.

\section{Results and Discussion}

Table 1 demonstrates the amplitude of the variables (minimum, maximum, and the coefficient of variation) in relation to the average of the evaluated parameters. Our analyses showed that the production of milk per hectare exhibited monthly amplitudes of 322, 375, 381, and $439 \mathrm{~L}$ of milk per hectare for summer, fall, winter, and spring, respectively. These amplitudes are considered normal and a result of the multifactorial nature of this variable and of differences in seasonal decisions (i.e. the number of lactating cows that can be altered by alimentary, nutritional, and reproductive management, and also by the commercialization of animals).

The price of milk in US dollars was highly variable, with minimum and maximum values as follows: summer $=0.2619$ USD and 0.5067 USD, fall $=0.3046$ USD and 0.5267 USD, winter $=$ 
0.2424 USD and 0.5163 USD, and spring $=0.2401$ USD and $0.4800 / \mathrm{L}$ USD. This is likely the result of fluctuations in the free market driven by supply and demand during the eight years of the study. In Brazil, milk prices are usually set by the company, with little room for negotiation. The changes in the value per $\mathrm{L}$ of milk were affected by bonuses received for the quantity produced and by the composition of the milk, which despite the differences between seasons (detailed below), still met the standards of the buyers.

The variables TDE, DDE, fat, protein, and lactose (Table 1) exhibited reduced coefficients of variation over the years and seasons. The composition of milk is largely dependent on herd genetics (Hardie et al., 2017; Knob, Alessio, Thaler, \& Mozzaquatro, 2018). However, feed and nutritional management contributed to the observed increases in these variables, since the milk bonus is paid in accordance with the fat and protein contents of the milk, in addition to the SCC and TBC values. Our data showed that the SCC and TBC data varied widely and were not normally distributed. Although some values were considered high, the average values demonstrated the potential for standardization in the production system. These trends are normal under the given production conditions and over the eight consecutive years of evaluation (2,920 d).

As expected, the THI also exhibited high coefficients of variation, owing to the meteorological conditions of Palmeira das Missões, Rio Grande do Sul, which experiences large fluctuations in temperature and humidity on both a daily and monthly basis.

As shown in Table 2, TDE is highly correlated with DDE, and fat content is weakly and moderately correlated with DDE and TDE, respectively. Protein content is weakly correlated with the price of milk (in USD) and fat content and is consistent with DDE and TDE. Lactose is weakly correlated with milk yield per hectare, the price of milk (in USD), TDE, and protein content, and is consistent with DDE.
The THI $<72$ was weakly correlated with milk yield per hectare, the price of milk (in USD), fat and lactose, and is consistent with DDE, TDE, and protein. In contrast, THI $>72$ exhibited the same Kendall correlations as THI $<72$, but showed the opposite relationships.

Milk production per hectare per month varied ( $p<0.0057)$ depending on the season (Table 3 ). It was higher in winter than in fall and summer, but did not significantly differ $(p>0.05)$ between winter and spring. There were no significant differences noted among summer, fall, and spring $(p>0.05)$. The milk production and total solids per hectare per year were 6,893 and 800 (2009); 8,336 and 972 (2010); 6,886 and 806 (2011); 6,104 and 722 (2012); 6,853 and 822 (2013); 5,598 and 667 (2014); 6,107 and 731 (2015); and 6,500 and 774 (2016), demonstrating a constant annual production despite THI variation and the effects of several other factors on pasture quantity and quality. Evaluating data between 2013 and 2017 from the "Programa de Producción Competitiva de CONAPROLE" (Fariña $\&$ Chilibroste, 2019) revealed that the average total solids production per hectare in Uruguay was 411 for a large drop in productivity; 539 for a medium drop; 621 for medium growth; and 627 for high growth. These results were obtained from cows fed dry matter composed of pasture, conserved forage, and concentrates.

Empresa de Assistência Técnica e Extensão Rural [EMATER] (2017), which evaluated the Productive Milk Chain of nearly all the municipalities in the State of Rio Grande do Sul, provided a standard value for milk production per hectare per year (3.324 L); however, this amount should be interpreted with caution and may not apply to semi-confinement or total confinement systems. The semi-confinement systems in the present study produced an average $6,666 \mathrm{~L}$ of milk per hectare per year over the course of eight years. Therefore, the average production in Rio Grande do Sul, Brazil, was $\sim 50 \%$ lower than that of the property investigated in the current study. 
It should be noted that the value of $6,666 \mathrm{~L}$ per hectare per year refers only to milk production. However, converting the monetary amounts received from the marketing of heifers and surplus cows into the milk that would have been produced, would add another 1,481 L per hectare per year, resulting in an increase of $22 \%(8,147 \mathrm{~L}$ of milk per hectare per year).

The land used for milk production could be converted to other uses, such as soybean cultivation. If we transform the value of milk production into the value of $60-\mathrm{kg}$ bags of soybeans produced over the same eight-year period and region, we can verify that this land would produce 100.6 bags of soybeans per hectare per year, which is double the average soybean yield of the state (50.1 bags per hectare in 2015) (Fundação de Economia e Estatística [FEEDADOS], 2015). This analysis of production and area indices suggests that the study area was more efficient than the average property in Rio Grande do Sul. However, this conclusion should not be based only on these two indicators, as they do not allow us to conclude whether production is sustainable.

There were no differences $(p>0.05)$ in milk prices, fat content, SCC, or TBC per season. Fat content, $\mathrm{SCC}$, and $\mathrm{TBC}$ are the main parameters evaluated in subsidies, as they affect the price received for milk (Botaro, Gameiro, \& Santos, 2013).

TDE content differed on a seasonal basis ( $p<$ 0.05 ) and was significantly lower in summer than in fall and winter, although the amounts did not differ significantly $(p>0.05)$ from the amount in spring. There were no significant differences in the TDE among fall, winter, and spring $(p<0.05)$. Our analyses also showed that the DDE content was significantly higher in winter than in other seasons $(p<0.05)$, while there were no significant differences in the DDE among summer, fall, and spring $(p>0.05)$. The protein content of milk significantly differed between summer and winter $(p<0.05)$, but did not differ between the other seasons $(p>0.05)$. In a recent study of Holstein cows on proteomics, Maity and Ambatipudi (2019) reported that a significant part of the variation in milk protein content is a function of the seasons. Milk contained a higher percentage of lactose in the winter $(p<0.05)$ than in the other seasons, which did not significantly differ from one another $(p>$ $0.05)$. Despite the economic relevance of lactose, its heritability in milk, and its significance as a nutrient in the dairy and pharmaceutical industries, in a few countries this carbohydrate has been used in milk bonus systems and has not been used in breeding programs (Costa et al., 2018, 2019).

Table 3

Statistical analysis of seasonal milk production in Escola Estadual Técnica Celeste Gobbato, Palmeira das Missões, Rio Grande do Sul, Brazil

\begin{tabular}{cccccc}
\hline Variable & Season ${ }^{1}$ & Adjusted mean & Lower CI & Upper CI & $p$-value \\
\hline \multirow{2}{*}{$\begin{array}{c}\text { Milk production per hectare per } \\
\text { month (kg) }\end{array}$} & Summer & $513.53 \mathrm{~B}$ & 459.14 & 567.93 & \\
& Fall & $504.69 \mathrm{~B}$ & 450.30 & 559.08 & 0.0057 \\
& Spring & $564.63 \mathrm{AB}$ & 510.23 & 619.02 \\
\hline \multirow{2}{*}{ Price of milk (USD/L) } & Summer & 0.3990 & 0.3838 & 0.4520 \\
& Fall & 0.4290 & 0.3949 & 0.4631 & 0.4533 \\
& Winter & 0.4179 & 0.3622 & 0.4303 & 0.4331
\end{tabular}


continuation

\begin{tabular}{|c|c|c|c|c|c|}
\hline \multirow{4}{*}{ Total dry extract $(\%)$} & Summer & 11.61B & 11.46 & 11.75 & \multirow{4}{*}{0.0059} \\
\hline & Fall & $11.93 \mathrm{~A}$ & 11.78 & 12.07 & \\
\hline & Winter & $11.97 \mathrm{~A}$ & 11.83 & 12.12 & \\
\hline & Spring & $11.79 \mathrm{AB}$ & 11.64 & 11.93 & \\
\hline \multirow{4}{*}{ Defatted dry extract (\%) } & Summer & $8.34 \mathrm{~B}$ & 8.26 & 8.42 & \multirow{4}{*}{0.0001} \\
\hline & Fall & $8.48 \mathrm{~B}$ & 8.40 & 8.56 & \\
\hline & Winter & $8.65 \mathrm{~A}$ & 8.57 & 8.73 & \\
\hline & Spring & $8.45 \mathrm{~B}$ & 8.37 & 8.52 & \\
\hline \multirow{4}{*}{ Fat $(\%)$} & Summer & 3.27 & 3.16 & 3.38 & \multirow{4}{*}{0.1457} \\
\hline & Fall & 3.45 & 3.34 & 3.55 & \\
\hline & Winter & 3.33 & 3.23 & 3.44 & \\
\hline & Spring & 3.34 & 3.23 & 3.45 & \\
\hline \multirow{4}{*}{ Protein $(\%)$} & Summer & $3.01 \mathrm{~B}$ & 2.94 & 3.08 & \multirow{4}{*}{0.0200} \\
\hline & Fall & $3.13 \mathrm{AB}$ & 3.06 & 3.20 & \\
\hline & Winter & $3.16 \mathrm{~A}$ & 3.09 & 3.23 & \\
\hline & Spring & $3.05 \mathrm{AB}$ & 2.98 & 3.12 & \\
\hline \multirow{4}{*}{ Lactose $(\%)$} & Summer & $4.41 \mathrm{~B}$ & 4.37 & 4.45 & \multirow{4}{*}{0.0011} \\
\hline & Fall & $4.41 \mathrm{~B}$ & 4.37 & 4.45 & \\
\hline & Winter & $4.52 \mathrm{~A}$ & 4.48 & 4.56 & \\
\hline & Spring & $4.43 \mathrm{~B}$ & 4.39 & 4.47 & \\
\hline \multirow{4}{*}{ Somatic cell count $(\mathrm{x} 1000 / \mathrm{mL})$} & Summer & 278 & 221 & 349 & \multirow{4}{*}{0.7761} \\
\hline & Fall & 272 & 216 & 342 & \\
\hline & Winter & 242 & 193 & 304 & \\
\hline & Spring & 279 & 222 & 351 & \\
\hline \multirow{4}{*}{$\begin{array}{l}\text { Total bacterial count }(\mathrm{x} 1000 / \\
\mathrm{mL})\end{array}$} & Summer & 50 & 34 & 75 & \multirow{4}{*}{0.0675} \\
\hline & Fall & 26 & 17 & 39 & \\
\hline & Winter & 44 & 29 & 66 & \\
\hline & Spring & 51 & 34 & 77 & \\
\hline \multirow{4}{*}{$\begin{array}{c}\text { Temperature-humidity index less } \\
\text { than } 72(\%)\end{array}$} & Summer & $51 \mathrm{C}$ & 47 & 55 & \multirow{4}{*}{$<0.000$} \\
\hline & Fall & $89 \mathrm{~A}$ & 82 & 97 & \\
\hline & Winter & $93 \mathrm{~A}$ & 86 & 101 & \\
\hline & Spring & $65 \mathrm{~B}$ & 60 & 70 & \\
\hline \multirow{4}{*}{$\begin{array}{l}\text { Temperature-humidity index } \\
\text { greater than } 72(\%)\end{array}$} & Summer & $46 \mathrm{~A}$ & 33 & 63 & \multirow{4}{*}{$<0.000$} \\
\hline & Fall & $6 \mathrm{~B}$ & 4 & 9 & \\
\hline & Winter & $6 \mathrm{~B}$ & 4 & 8 & \\
\hline & Spring & $30 \mathrm{~A}$ & 22 & 42 & \\
\hline
\end{tabular}

${ }^{1}$ Season = 1: Summer = January, February, March; 2: Fall = April, May, June; 3: Winter = July, August, September; 4: Spring = October, November, December. Seasons according to the Southern Hemisphere. Different uppercase letters after averages in the same line indicate significant differences (Tukey-Kramer test, $p<0.05$ ). 
The variable THI $<72$ was highest in the fall and winter seasons but the values were not significantly different $(p>0.05)$ from each other. However, THI $<72$ values in fall and winter were significantly higher than in spring and summer $(p<0.0001)$. The percentage of THI $>72$ values was significantly greater in the spring and summer than in fall and winter $(p<0.0001)$, while there was no significant difference between spring and summer or fall and winter $(p>0.05)$. The effect of heat stress is accentuated when cows are exposed to stressful conditions for two to four consecutive days, and multiparous cows suffer more and may reduce production of milk by one kilogram per day (Bernabucci et al., 2014).

Our findings highlighted the importance of season on the composition of milk; however, because the variations in the fat, protein, and lactose content are correlated with TDE and DDE, and are influenced by the THI, we have discussed these findings together. This combined discussion is justified by the concepts of homeostasis and homeorhesis according to Bauman and Currie (1980), in which the final composition of the milk in the expansion tank is the result of the interactions among all the metabolic functions of the cows, as well as the characteristics of the herd (e.g., the lactation phase). The relatively small variation in the constituents of milk is largely attributed to the consistency of the nutritional management strategy (i.e. semi-confinement), as more than $50 \%$ of the diet is consumed from the trough and nutrition has less variation than in the pastures, which are affected by photosynthetic conditions, soil fertility, etc.

Gonçalves et al. (2018) evaluated Brazilian databases and found that a high SCC results in daily losses, noticeable even at values of only 12,400 cells per $\mathrm{mm}$. Therefore, the SCC needs to be reduced in Brazilian commercial herds to increase cow and per hectare performance, as investments in genetics and land are already high. The TBC must also be reduced, as it is a reflection of poor hygiene practices during milking and the cooling of the milk. The mean values of SCC and TBC observed in the present study could be reduced; however, considering that they are the averages of eight consecutive years, and meet the standards of normative instructions Nos. 76 and 77 (Instrução Normativa $\left.\mathrm{n}^{\mathrm{o}} 76,77,2018 \mathrm{a}, \mathrm{b}\right)$, they are typical values that farmers may be expected to reach, and further reductions would require special efforts. The Escola Estadual Técnica Celeste Gobbato may be able to assist in reducing these values by serving as a technology diffusion center for rural producers in the region and providing training courses that could substantially assist rural dairy operations.

Figures 4 and 5 show the milk production per hectare and per month; however, in Figure 4, the graph is continuous (January 2009 to December 2016) to emphasize that this parameter is quite variable over the years because milk production is an important factor in planning investments in the operation. Figure 5 shows the same data from January to December of each year to reveal similarities in behaviors on a seasonal basis. Visualizing the data in this way revealed that during the last two months of fall (May and June), milk production per hectare per month began to increase. Yields were the highest in winter, when the pastures had better nutritional quality and the lowest percentage of $\mathrm{THI}>72$. Body temperatures rise rapidly as the ambient temperatures increase, demonstrating the need to manage heat stress in dairy environments, but the relationship between ambient temperature and reticulum-rumen temperature is nonlinear, indicating that cows are very sensitive to changes in ambient temperature (Liang et al., 2013). 


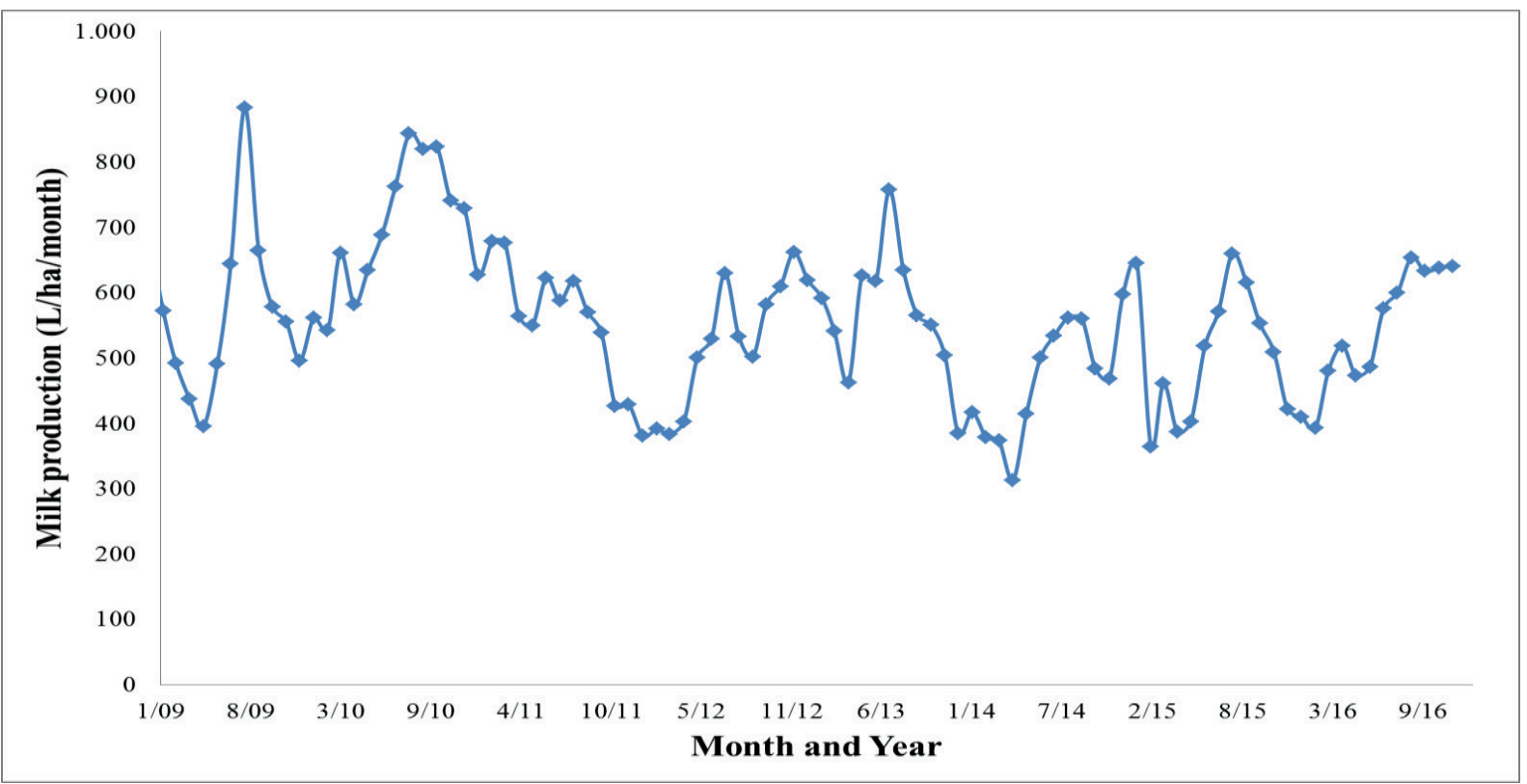

Figure 4. Visualization of milk production per hectare per month from January 2009 to December 2016 in Palmeira das Missões, Rio Grande do Sul, Brazil.

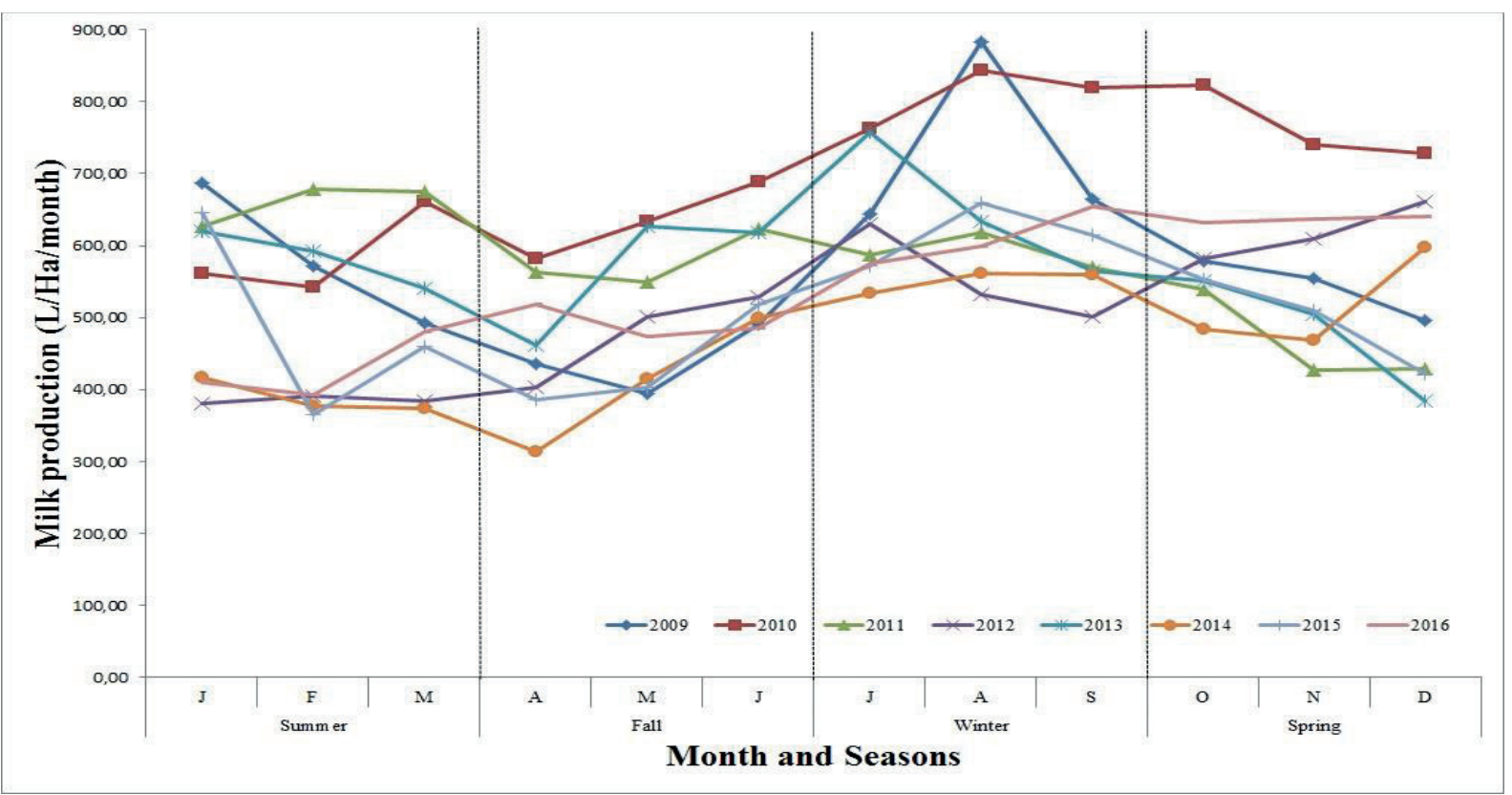

Figure 5. Visualization of milk production per hectare per month in Palmeira das Missões, Rio Grande do Sul, Brazil between January and December for each year evaluated.

Most studies on dairy cow management the modeling of specific empirical effects (Martin and feeding have been conducted over short experimental periods, using static statistical designs (e.g., Latin square and crossover) that only allow \& Sauvant, 2002). Despite these challenges, it is well accepted that dairy cow nutrition should be based on dynamic models, as the lactation curve 
reflects the interdependence of the different stages of lactation. Martin and Sauvant (2002) selected 37 studies published between 1959 and 1999 to study the effects on lactation of DMI (dry matter intake; 10.1-24.7 kg DM/day), RMP (raw milk production; 15.5-44.4 kg/cow/day), and LW (live weight; 320$573 \mathrm{~kg}$ ). Their meta-analysis confirmed that over the course of this 40-year period, the variables had increased by $6.6 \mathrm{~kg}$ for DMI, $15.3 \mathrm{~kg}$ for RMP, and $51 \mathrm{~kg}$ in LW as a result of genetic improvement and better management conditions. These improvements resulted in an annual increase of $165 \mathrm{~kg}$ in milk per lactation at 44 weeks. They concluded that dairy cow management should consider voluntary intake and production, the mobilization of body reserves in the initial phase of lactation, and a nutritional plan that meets the energy requirements of the cows in the initial phase of lactation, as this approach prevents decreased milk production and decreased fat in the subsequent stages of lactation.

Longitudinal retrospective studies allow for evaluations that can be extrapolated to rural properties (Sargeant \& O'Connor, 2014). According to Bello \& Renter (2018), reproducible results are the nucleus of scientific integrity in modern research, which requires interdisciplinary work in the animal sciences to maximize the reproducibility of the research results.

\section{Conclusions}

This consecutive longitudinal retrospective study, covering eight years, emphasizes that the execution of activities related to dairy farming in a planned manner reduces the coefficients of variation in the composition of milk. In other words, a more holistic and integrative approach makes it easier to maintain milk quality, as well as generate extra revenue from the quality bonuses. The normative instructions Nos. 76, 77, and 78 from the Ministério da Agricultura, Pecuária e Abastecimento can guide dairy farmers to improve milk production systems as a whole, bearing in mind that since the activity is multifactorial by nature, improving only one or two indexes will not yield optimal results. In addition, milk production clearly varies by season; however, with the use of bulk feeds throughout the year and with an increased supply of concentrates, it is possible to minimize or even nullify the effect of the traditional fodder voids in fall and spring. Winter is the most favorable season for milk production. Furthermore, the temperature and humidity index increases the frequency of heat stress in summer. The management of milk production systems in the rural areas investigated in the present study enabled an average production that was twice the state average, although it is possible to improve performance even more with a fully integrated agricultural production system that recycles more nutrients.

\section{Acknowledgments}

This study was supported by the Financiadora de Estudos e Projetos (FINEP) of the Ministério da Ciência e Tecnologia (MCT) through the Public Call MCT/FINEP/CT-INFRA-CAMPI REGIONAL-01/2010. This study was financed in part by the Coordenação de Aperfeiçoamento de Pessoal de Nível Superior - Brasil (CAPES; Finance Code 001). We thank the Fundo de Incentivo à Pesquisa da Universidade Federal de Santa Maria (FIPE - UFSM) for the grant awarded to Júlia Laize Bandeira Calgaro. We also thank the Conselho Nacional de Desenvolvimento Científico e Tecnológico ( $\mathrm{CNPq}$ ) for the grant awarded to Jardel Menegazzi da Conceição.

\section{References}

Alexandratos, N., \& Bruinsma, J. (2012). World agriculture towards 2030/2050: the 2012 revision. ESA Working paper n. 12-03. Rome: FAO.

Almeida, C. O., \& Bacha, C. J. C. (1999). Evolução da política cambial e da taxa de câmbio no Brasil, 1961-71. Pesquisa \& Debate. Revista do Programa de Estudos Pós-Graduados em Economia Política, 10(16), 5-29. 
Alvares, C. A., Stape, J. L., Sentelhas, P. C., Gonçalves, J. L. de M., \& Sparovek, G. (2013). Köppen's climate classification map for Brazil. Meteorologische Zeitschrift, 22(6), 711-728. doi: 10.1127/09412948/2013/0507

Asselin-Balençon, A. C., Popp, J., Henderson, A., Heller, M., Thoma, G., \& Jolliet, O. (2013). Dairy farm greenhouse gas impacts: A parsimonious model for a farmer's decision support tool. International Dairy Journal, 31(Supl. 1), S65-S77. doi: 10.1016/j. idairyj.2012.09.004

Bauman, D. E., \& Currie, W. B. (1980). Partitioning of nutrients during pregnancy and lactation: A review of mechanisms involving homeostasis and homeorhesis. Journal of Dairy Science, 63(9), 15141529. doi: $10.3168 / j \mathrm{ds} . S 0022-0302(80) 83111-0$

Bello, N. M., \& Renter, D. G. (2018). Reproducible research from noisy data: Revisiting key statistical principles for the animal sciences. Journal of Dairy Science, 101(7), 5679-5701. doi: 10.3168/jds.201713978

Bernabucci, U., Biffani, S., Buggiotti, L., Vitali, A., Lacetera, N., \& Nardone, A. (2014). The effects of heat stress in Italian Holstein dairy cattle. Journal of Dairy Science, 97(1), 471-486. doi: 10.3168/ jds.2013-6611

Botaro, B. G., Gameiro A. H., \& Santos, M. V. dos. (2013). Quality based payment program and milk quality in dairy cooperatives of Southern Brazil: an econometric analysis. Scientia Agricola 70(1), 2126. doi: 10.1590/S0103-90162013000100004

Bresser-Pereira, L. C. (2012). A taxa de câmbio no centro da teoria do desenvolvimento. Estudos Avançados, 26(75), 7-28. doi: 10.1590/S010340142012000200002

Busanello, M., Rossi, R. S., Cassoli, L. D., Pantoja, J. C. F., \& Machado, P. F. (2017). Estimation of prevalence and incidence of subclinical mastitis in a large population of Brazilian dairy herds. Journal of Dairy Science, 100(8), 6545-6553. doi: 10.3168/ jds.2016-12042

Coimbra, P. A. D., Machado, L. C. P., Fº, \& Hötzel, M. J. (2012). Effects of social dominance, water trough location and shade availability on drinking behaviour of cows on pasture. Applied Animal Behaviour Science, 139(3-4), 175-182. doi: 10.1016/j. applanim.2012.04.009

Costa, A., Lopez-Villalobos, N., Sneddon, N. W., Shaloo, L., Franzoi, M., De Marchi, M., \& Penasa, M. (2019). Invited review: Milk lactose - current status and future challenges in dairy cattle. Journal of Dairy Science, 102(7), 5883-5898. doi: 10.3168/ jds.2018-15955

Costa, A., Lopez-Villalobos, N., Visentin, G., Marchi, M. de, Cassandro, M., \& Penasa, M. (2018). Heritability and repeatability of milk lactose and its relationships with traditional milk traits, somatic cell score and freezing point in Holstein cows. Animal, 13(5), 909916. doi: $10.1017 /$ S1751731118002094

Empresa de Assistência Técnica e Extensão Rural (2017). Rio Grande do Sul/ASCAR. Relatório socioeconômico da cadeia produtiva do leite no Rio Grande do Sul. Porto Alegre: Emater/RS-Ascar.

Fajardo, M., Mattiauda, D. A., Motta, G., Genro, T. C., Meikle, A., Carriquiry, M., \& Chilibroste, P. (2015). Use of mixed rations with different access time to pasture land on productive responses of early lactation Holstein cows. Livestock Science, 181(1), 51-57. doi: 10.1016/j.livsci.2016.09.023

Fariña, S. R., \& Chilibroste, P. (2019). Opportunities and challenges for the growth of milk production from pasture: The case of farm systems in Uruguay. Agricultural Systems, 176(1), 102631. doi: 10.1016/j. agsy.2019.05.001

Ferlay, A., Doreau, M., Martin, C., \& Chilliard, Y. (2013). Effects of incremental amounts of extruded linseed on the milk fatty acid composition of dairy cows receiving hay or corn silage. Journal of Dairy Science, 96(10), 6577-6595. doi: 10.3168/jds.2013-6562

Fundação de Economia e Estatística (2015). Estatísticas. Porto Alegre: Fundação de Economia e Estatística. Recuperado de http://www.fee.rs.gov.br/

Gantner, V., Bobic, T., Gantner, R., Gregic, M., Kuterovac, K., Novakovic, J., \& Potocnik, K. (2017). Differences in response to heat stress due to production level and breed of dairy cows. International Journal of Biometeorology, 61(9), 1675-1685. doi: 10.1007/ s00484-017-1348-7

Gerssen-Gondelach, S. J., Lauwerijssen, R. B. G., Havlík, P., Herrero, M., Valin, H., Faaij, A. P. C., \& Wicke, B. (2017). Intensification pathways for beef and dairy cattle production systems: impacts on GHG emissions, land occupation and land use change. Agriculture, Ecosystems \& Environment, 240(1), 135-147. doi: 10.1016/j.agee.2017.02.012

Gonçalves, J. L., Cue, R. I., Botaro, B. G., Horst, J. A., Valloto, A. A., \& Santos, M. V. (2018). Milk losses associated with somatic cell counts by parity and stage of lactation. Journal of Dairy Science, 101(5), 4357-4366. doi: 10.3168/jds.2017-13286 
Grijó, R. T. (2005). A Taxa de câmbio real e o saldo da balança comercial brasileira no pós plano Real. Dissertação de mestrado, Fundação Instituto Capixaba de Pesquisas em Contabilidade, Economia e Finanças, Vitória, ES, Brasil.

Hardie, L. C., Van de Haar, M. J., Tempelman, R. J., Weigel, K. A., Armentano, L. E., Wiggans, G. R.,... Spurlock, D. M. (2017). The genetic and biological basis of feed efficiency in mid-lactation Holstein dairy cows. Journal of Dairy Science, 100(11), 9061-9075. doi: 10.3168/jds.2017-12604.

Haygert-Velho, I. M. P., Conceição, G. M. da, Cosmam, L. C., Alessio, D. R. M., Busanello, M., Sippert, M. R.,... Velho, J. P. (2018). Multivariate analysis relating milk production, milk composition, and seasons of the year. Anais da Academia Brasileira de Ciências, 90(4), 3839-3852. doi: 10.1590/00013765201820180345

Hentz, F., Velho, J. P., Nörnberg, J. L., HaygertVelho, I. M. P., Henz, E. L., Henn, J. D.,... Zardin, P. B. (2017). Fractionation of carbohydrates and nitrogenous constituents of late-crop corn silages ensiled with different specific masses. Semina: Ciências Agrárias, 38(1), 491-502. doi: 10.5433/1679-0359.2017v38n1p491

Henz, E. L., Gois de Almeida, P. S, Velho, J. P., Nörnberg, J. L., Silva, L. das D. da, Backes, T. R., \& Guerra, G. L. (2016). Dual purpose wheat production with different levels of nitrogen topdressing. Semina: Ciências Agrárias, 37(2), 1091-1100. doi: 10.5433/1679-0359.2016v37n2p1091

Holly, M. A., Larsona, R. A., Powell, J. M., Ruark, M. D., \& Aguirre-Villegas, H. (2017). Greenhouse gas and ammonia emissions from digested and separated dairy manure during storage and after land application. Agriculture, Ecosystems \& Environment, 239(1), 410-419. doi: 10.1016/j.agee.2017.02.007

Instituto Brasileiro de Economia - Fundação Getúlio Vargas (2016). Índice geral de preços disponibilidade interna - metodologia. Rio de Janeiro: Fundação Getúlio Vargas.

Instrução Normativa $n^{\circ} 76$, de 30 de novembro de 2018. (2018a). Brasília: Diário Oficial da União 1, 9-10.

Instrução Normativa $n^{\circ} 77$, de 30 de novembro de 2018. (2018b). Brasília: Diário Oficial da União 1, 10-13.0.

Instrução Normativa $n^{\circ} 78$, de 30 de novembro de 2018. (2018c). Brasília: Diário Oficial da União 1, 13-17.

Kibler, H.H. (1964) Thermal effects of various temperature-humidity combinations on Holstein cattle as measured by eight physiological responses.
University of Missouri Agricultural Experiment Station, Research Bulletin Missouri Agricultural Experiment Station, 862, 1-42.

Knob, D. A., Alessio, D. R. M., Thaler, A., Neto, \& Mozzaquatro, F. D. (2018). Growth, productive performance, and udder health of crossbred Holstein $\mathrm{x}$ Simmental cows and purebred Holstein cows. Semina: Ciências Agrárias, 39(6), 2597-2606. doi: 10.5433/1679-0359.2018v39n6p2597

Kraub, M., Kraatz, S., Drastig, K., \& Prochnow, A. (2015). The influence of dairy management strategies on water productivity of milk production. Agricultural Water Management, 147(1), 175-186. doi: 10.1016/j.agwat.2014.07.015

Larsen, M. K., Nielsen, J. H., Butler, G., Leifert, C., Slots, T., Kristiansen, G. H., \& Gustafsson, A. H. (2010). Milk quality as affected by feeding regimens in a country with climatic variation. Journal Dairy Science, 93(7), 2863-2873. doi: 10.3168/jds.20092953

Liang, D., Wood, C. L., McQuerry, K. J., Ray, D. L., Clark, J. D., \& Bewley, J. M. (2013). Influence of breed, milk production, season, and ambient temperature on dairy cow reticulorumen temperature. Journal of Dairy Science, 96(8), 5072-5081. doi: 10.3168/ jds.2012-6537

Liu, J., Mooney, H., Hull, V., Davis, S. J., Gaskell, J., Hertel, T., ... Gleick, P. (2015). Systems integration for global sustainability. Science, 347(6225), 963972. doi: $10.1126 /$ science. 1258832

Maity, S., \& Ambatipudi, K. (2019). Quantitative proteomics of milk whey reveals breed and season specific variation in protein abundance in Holstein Friesian cow and Murrah buffalo. Research in Veterinary Science, 125(8), 244-252. doi: 10.1016/j. rvsc.2019.07.001

Martin, O., \& Sauvant, D. (2002). Metaanalysis of input/ output kinetics in lactating dairy cows. Journal of Dairy Science, 85(12), 3363-3381. doi: 10.3168/jds. S0022-0302(02)74424-X

Min, L., Zhao, S., Tian, H., Zhou, X., Zhang, Y., Li, S.,... Wang, J. (2017). Metabolic responses and "omics" technologies for elucidating the effects of heat stress in dairy cows. International Journal Biometeorology, 61(6), 1149-1158. doi: 10.1007/s00484-016-1283-z

Mueller, C., Baan, L. de, \& Koellner, T. (2014). Comparing direct land use impacts on biodiversity of conventional and organic milk based on a Swedish case study. The International Journal of Life Cycle Assessment, 19(1), 52-68. doi: 10.1007/s11367-013-0638-5 
Oeffner, S. P., Qu, Y., Just, J., Quezada, N., Ramsing, E., Keller, M.,... Bobe, G. (2013). Effect of flaxseed supplementation rate and processing on the production, fatty acid profile, and texture of milk, butter, and cheese. Journal of Dairy Science, 96(2), 1177-1188. doi: 10.1590/S151635982001000200010

Oliveira, J. B. D., Neto, Moura, A. D. A. A., Neiva, J. N. M., \& Guilhermino, M. M. (2001). Indicadores de estresse térmico e utilização da somatotropina bovina (bST) em vacas leiteiras mestiças (Bos taurus $\times$ Bos indicus) no semi-árido do Nordeste. Revista Brasileira de Zootecnia, 30(2), 360-367. doi: 10.1590/S1516-35982001000200010

Palhares, J. C. P., \& Pezzopane, J. R. M. (2015). Water footprint accounting and scarcity indicators of conventional and organic dairy production systems. Journal of Cleaner Production, 93(1), 299-307. doi: 10.1016/j.jclepro.2015.01.035

Patz, J. A., Campbell-Lendrum, D., Holloway, T., \& Foley, J. A. (2005). Impact of regional climate change on human health. Nature, 438(7066), 310317. doi: $10.1038 /$ nature 04188

Puppel, K., Kuczyńska, B., Nałęcz-Tarwacka, T., \& Grodzki, H. (2013). Influence of linseed variety in fatty acid profile in cow's milk. Journal of the Science of Food and Agriculture, 93(9), 2276-2280. doi: $10.1002 /$ jsfa. 6037

Rangel, A. H. N., Araujo, T. P. M., Lima, G. F. C., Borba, L. H. F., Peixoto, M. G. C. D., \& Lima, D. M. Jr. (2018). Estimation of genetic and phenotypic trends for dairy traits of Gyr and Guzerá breeds. Acta Scientiarum. Animal Sciences, 40(35685). doi: 10.4025/actascianimsci

Roche, J. R., Berry, D. P., Bryant, A. M., Burke, C. R., Butler, S. T., Dillon, P. G.,... Macmilan, K. L. (2017). A 100-year review: a century of change in temperate grazing dairy systems. Journal of Dairy Science, 100(12), 10189-10233. doi: 10.3168/jds.2017-13182

Salomon, J. A., Wang, H., Freeman, M. K., Vos, T., Flaxman, A. D., Lopez, A. D., \& Murray, C. J. (2012). Healthy life expectancy for 187 countries, 1990-2010: a systematic analysis for the Global Burden Disease Study 2010. The Lancet, 380(9859), 2144-2162. doi: 10.1016/S0140-6736(12)61690-0

Samir, K. C., \& Lutz, W. (2017). The human core of the shared socioeconomic pathways:Populationscenarios by age, sex and level of education for all countries to 2100. Global Environmental Change, 42(1), 181192. doi: 10.1016/j.gloenvcha.2014.06.004
Sargeant, J. M., \& O'Connor, A. M. (2014). Issues of reporting in observational studies in veterinary medicine. Preventive Veterinary Medicine, 113(3), 323-330. doi: 10.1016/j.prevetmed.2013.09.004

Seto, C. K., \& Ramankutty, N. (2016). Hidden linkages between urbanization and food systems. Science, 352(6288), 943-945. doi: 10.1126/science.aaf7439

Silva, D. C. da, Santos, G. T., Branco, A. F., Damasceno, J. C., Kazama, R., Matsushita, M.,... Petit, H. V. (2007). Production performance and milk composition of dairy cows fed whole or ground flaxseed with or without monensin. Journal of Dairy Science, 90(6), 2928-2936. doi: 10.3168/jds.2006-573

Silva, N. C. da, Nascimento, C. F., Nascimento, F. A., Resende, F. D. de, Daniel, J. L. P., \& Siqueira, G. R. (2018). Fermentation and aerobic stability of rehydrates corn grain silage treated with different doses of Lactobacillus buchneri or a combination of Lactobacillus plantarum and Pediococcus acidilactici. Journal of Dairy Science, 101(5), 41584167. doi: 10.3168/jds.2017-13797

Silva, R. P. A. da, Thaler, A., Neto, Cobuci, J. A., Valloto, A. A., Horst, J. A., \& Ribas, P. G., Neto. (2015). Correlações genéticas entre algumas características de tipo e intervalo de partos em vacas da raça Holandesa. Arquivo Brasileiro de Medicina Veterinária e Zootecnia, 67(1), 166-172. doi: 10.1590/1678-6445

Smith, D. A. (2017). World city populations 1950-2030: proportional circle time series map. Environment and Planning A: Economy and Space, 49(1), 3-5. doi: $10.1177 / 0308518 X 16641414$

Statistical Analysis System Institute (2012). Release 8.02. 2000. Cary: SAS Inst. Inc.

Stürmer, M., Busanello, M., Velho, J. P., Heck, V. I., \& Haygert-Velho, I. M. P. (2018). Relationship between climatic variables and the variation in bulk tank milk composition using canonical correlation analysis. International Journal of Biometeorology, 62(9), 1663-1674. doi: 10.1007/s00484-018-1566-7

Tambara, A. A. C., Sippert, M. R., Jauris, G. C., Flores, J. L. C., Henz, E. L., \& Velho, J. P. (2017). Production and chemical composition of grasses and legumes cultivated in pure form, mixed or in consortium. Acta Scientiarum. Animal Sciences, 39(3), 235-241. doi: $10.4025 /$ actascianimsci

Tedeschi, L. O., Fonseca, M. A., Muir, J. P., Poppi, D. P., Cartens, G. E., Angerer, J. P., \& Fox, D. G. (2017). Invited review: A glimpse of the future in animal nutrition science. 2. Current and future solutions. 
Revista Brasileira de Zootecnia. 46(5), 452-469. doi: 0.1590/s1806-92902017000500012

Tedeschi,L.O., Muir,J.P., Riley,D.G., \&Fox,D.G.(2015). The role of ruminant animals in sustainable livestock intensification programs. International Journal of Sustainable Development \& World Ecology, 22(5), 452-465. doi: 10.1080/13504509.2015.1075441

Valin, H., Sands, R. D., Mensbrugghe, D., Nelson, G. C., Ahammad, H., Blanc, E.,... Willenbockel, D. (2014). The future of food demand: understanding differences in global economic models. Agricultural Economics, 45(1), 51-67. doi: 10.1111/agec.12089

Velho, J. P., Zardin, P. B., Jobim, C. C., Haygert-Velho, I. M. P., Alessio, D. R. M., Giotto, E..,... Gehrke, C. R. (2020). Meta-analysis of corn plants, green fodder (ensilage), and silages of different types of maize hybrids used in experimental conditions in Brazil. Semina: Ciências Agrárias, 41(1), 239-256. doi: 10.5433/1679-0359.2020v41n1p239
Veltman, K., Jones, C. D., Gaillard, R., Cela, S., Chase, L., Duval, B. D.,... Jolliet, O. (2017). Comparison of process-based models to quantify nutrient flows and greenhouse gas emissions associated with milk production. Agriculture, Ecosystems \& Environment, 237(1), 31-44. doi: 10.1016/j.agee.2016.12.018

Virbat, R. E., Tavendale, M., Otter, D., Schwendel, B. H., Lowe, K., Gregorini, P., \& Pacheco, D. (2017). Milk production and composition, nitrogen utilization, and grazing behavior of late-lactation dairy cows as affected by time of allocation of a fresh strip of pasture. Journal of Dairy Science, 100(7), 53055318. doi: 10.3168/jds.2016-12413

Willers, C. D., Ferraz, S. P., Carvalho, L. S., \& Rodrigues, L. C. (2014). Determination of indirect water consumption and suggestions for cleaner production initiatives for the milk-producing sector in a Brazilian middle-sized dairy farming. Journal of Cleaner Production, 72(1), 146-152. doi: 10.1016/j. jclepro.2014.02.055 